(c) American Dairy Science Association, 2005.

\title{
Characterization of Days Dry for United States Holsteins
}

\author{
M. T. Kuhn, J. L. Hutchison, and H. D. Norman \\ Animal Improvement Programs Laboratory, Agricultural Research Service, \\ USDA, Beltsville, MD 20705-2350
}

\section{ABSTRACT}

This research characterized days dry (DD) for modern US Holsteins. This included investigation of factors influencing DD, summarizing variation in herd means as well as within-herd variation, and estimation of parameters related to DD. Data consisted of records initiated before 2003 from cows first calving after 1996. A total of 459,075 records from 295,067 cows in 3527 herds were included. The overall mean DD was $60.5 \mathrm{~d}$, and standard deviation among herd means was $5.8 \mathrm{~d}$. Approximately $91 \%$ of all herds had mean DD between 50 and $70 \mathrm{~d}$. There were 41 herds that had mean DD of $\leq 45 \mathrm{~d}$ and 2 herds with mean DD of $\leq 30 \mathrm{~d}$. Some herds (125) had unusually long mean DD (exceeding $71 \mathrm{~d}$ ). Variation across regions of the United States was minimal, although southwestern herds did show somewhat longer DD than other regions. Days open (DO) accounted for the most variation in DD with longer DO leading to longer dry periods. Heritability of DD was $7 \%$ and repeatability $12 \%$. Error correlations indicated that longer dry periods benefit both milk yield and somatic cell score in the subsequent lactation. Genetic and permanent environmental correlations were large, which indicated that 1) bias would result if genetic evaluations for milk yield included an adjustment for $\mathrm{DD}$, and 2) correction for cow effects is warranted in estimation of DD effects on performance. The relationship between DD and DO is due primarily to permanent cow effects. Improved fertility will enhance the feasibility of shortened dry periods.

(Key words: days dry, days open)

Abbreviation key: DD = days dry, $\mathbf{D O}=$ days open, $\mathbf{P E}=$ permanent environment.

\section{INTRODUCTION}

Optimum length of dry period has become a popular topic in recent years as evidenced by numerous popular

Received October 18, 2004

Accepted November 9, 2004

Corresponding author: Melvin Kuhn; e-mail: mkuhn@aipl. arsusda.gov. press articles (Annen et al., 2003; Rastani and Grummer, 2003; Bachman, 2004; Grummer, 2004). Both past and present research has focused primarily on the effect of days dry (DD) on performance in the subsequent lactation (Schaeffer and Henderson, 1972; Coppock et al., 1974; Dias and Allaire, 1982; Funk et al., 1987; Makuza and McDaniel, 1996; Bachman, 2002). A few studies (Schaeffer and Henderson, 1972; Funk et al., 1987; Makuza and McDaniel, 1996) reported parameters such as heritability of DD or the genetic and environmental correlations with other economically important traits. However, there appears to be little, if any, research indicating what factors affect producer decisions on when to dry off cows. The extent of withinor across-herd variation in DD is also unknown.

Characterization of factors affecting DD can be useful to extension and consulting personnel, researchers, and dairy producers. To formulate management recommendations, extension scientists and other consultants need to first be familiar with current practices. For research aimed at delineating the dry period length to maximize performance, knowledge of factors affecting DD can be useful in determining appropriate models for field data or factors to control in designed studies. Finally, although dairy producers are no doubt aware of what factors affect their individual decisions to dry off cows, the extent that various factors play overall may be largely unknown. More insight might lead to improved management practices.

Given within-herd variation for DD and evidence for its effect on subsequent lactation milk yield, several researchers have advocated adjustment for DD in genetic evaluation for production (Funk et al., 1987; Makuza and McDaniel, 1996). Estimates of genetic correlations, however, are critical in evaluating the propriety of this recommendation. If the genetic correlation between 2 traits differs from zero, then adjusting one trait for the other in genetic evaluation redefines the trait being evaluated. The genetic evaluations for the redefined trait are biased with respect to the original, unadjusted trait. Estimates of genetic, permanent environment (PE), and error correlations of DD with other economically important traits can also be useful in research aimed at determining the effects of DD on performance. For example, if genetic and PE correlations with 
performance are not zero, this would indicate that adjustment for cow effects is warranted in estimation of DD effects on performance.

The purpose of this research was to characterize DD for modern US Holsteins. This included summarization of variation in herd means as well as within herd variability for DD, determination of factors affecting DD, and estimation of parameters related to DD including heritability and genetic and environmental correlations with other economically important traits.

\section{MATERIALS AND METHODS}

\section{Data}

Data used in this study were DHI records from the national database of the Animal Improvement Programs Laboratory, USDA (Beltsville, MD). Only data from Holstein cows that first calved after 1996 were included because DD was not available for earlier calvings. To ensure that only complete lactations were used, calving date was required to be before 2003. Each herd was required to have been on test for the entire period from 1997 through 2003 to ensure nearly complete information for cows initiating their records late in 2002. If a herd had any year with $<5$ cows, the entire herd was eliminated.

There are numerous DHI testing plans for US herds. Some plans involve herd owners taking the measurements themselves, rather than having an official DHI tester take milk weights and samples. Such records generally contain more error than supervised testing (Animal Improvement Programs Laboratory, 2004). Animal Improvement Programs Laboratory considers any record where more than $50 \%$ of the test-days were taken by the herd owner to be owner-sampled and these records must pass additional edits to be included in the national genetic evaluations (Animal Improvement Programs Laboratory, 2004a). Thus, to ensure quality of data, a herd's average owner-sampler percentage had to be less than $50 \%$ across the period specified to be included.

Because not all centers began sending complete lactation records at the same time, the date at which dry period length was available varied somewhat across dairy records processing centers. Thus, the January 1997 inclusion date had to be moved forward for some herds. This edit change applied primarily to herds processed by the 2 centers located in the western United States.

Records initiated by abortion were deleted. Cows known to be embryo transfer donors were also excluded because embryo transfer could lead to abnormally long dry periods or lactations. Days dry was required to be between 0 and $120 \mathrm{~d}$; dry periods longer than $120 \mathrm{~d}$ were deleted. Another important edit was that the expected calving date based on last reported days open (DO) and the actual calving date had to agree within $10 \mathrm{~d}$. Some researchers (Bachman and Schairer, 2003; Grummer, 2004) have argued that analyses using DHI data are biased because most short dry periods included are those that are unplanned, due to cows calving earlier than expected. They indicated that if the producers had known when the cows were going to calve, the cows would have been managed differently to deal with the short DD. Hence, this edit ensured that producers knew when cows were going to calve because, in effect, they reported it to DHI.

\section{Descriptive Statistics}

Within-herd standard deviations of DD were calculated and summarized by an overall mean and range. Within-herd standard deviations were also averaged by region. A frequency distribution of individual DD records, in contrast to herd mean $\mathrm{DD}$, was also calculated using dry periods up to the beginning of fifth lactation. For this distribution, no upper limit was placed on DD. This was the only analysis without the $\mathrm{DD} \leq 120 \mathrm{~d}$ requirement.

\section{Factors Affecting DD}

In this study, previous lactation was defined as the lactation preceding a given dry period and subsequent lactation as the lactation following a given dry period. For example, for the dry period between first and second lactations, the previous lactation is parity 1 , and the subsequent lactation is parity 2 .

In studies aimed at determining the effect of $\mathrm{DD}$, the dependent variable would be the trait of interest (e.g., milk yield) in the subsequent lactation, and DD would be included in the model as an independent variable for that trait. For such studies, the previous lactation is generally of little interest. However, to determine what factors affect DD, the opposite is true. For example, the first DD would be influenced by what occurred in the first, not second lactation (which had not occurred yet when the cow went dry). Thus, to determine to what extent various factors affect $\mathrm{DD}$, the dependent variable is $\mathrm{DD}$, and factors in the previous lactation are the independent variables of interest. The equation used for modeling DD was

$$
\begin{aligned}
\mathrm{DD} & =\text { Herd }+\mathrm{MO}+\mathrm{YR}+\text { Parity }+ \text { Age } \\
& +\mathrm{DO}+\text { Milk + Last_SCS + e },
\end{aligned}
$$

where DD is DD between previous and subsequent parities, MO is calving month, YR is calving year, Parity 
Table 1. Category means for lactational milk yield (kg), last testday SCS (SCS), and days open (DO).

\begin{tabular}{lrlr}
\hline Category & \multicolumn{1}{c}{ Milk } & SCS & DO \\
\hline 1 & 7905 & 1.4 & 67 \\
2 & 10,357 & 3.1 & 111 \\
3 & 13,886 & 5.2 & 210 \\
\hline
\end{tabular}

is lactation number $(1,2, \ldots, 6)$, Age, Milk, and Last_SCS were categorical variables for age at calving, actual lactational milk yield, and last test-day SCS, respectively, and e was a random error. All effects were fit as fixed effects and were from the previous lactation.

Calving age categories were defined as 1) $<24 \mathrm{mo}, 2$ ) 24 to $<30 \mathrm{mo}, 3) 30$ to $<36 \mathrm{mo}, 4) 36$ to $<42 \mathrm{mo}, 5) 42$ to $<48 \mathrm{mo}$, and 6 ) $\geq 48 \mathrm{mo}$. Age categories were largely nested within parity. Thus, the effect of age investigated here is an age effect, beyond parity or within parity. Categories for milk, SCS, and DO were defined as 1) lower third of data sorted by each trait, 2) middle third, and 3) top third. Actual milk yields were calculated from test-day yields using the test-interval method (Sargent et al., 1968) and lactation-shape adjustment factors (Shook et al., 1980). A total of 459,075 records from 295,067 cows in 3527 herds were included in this analysis. The mean of each category for milk, SCS, and DO is given in Table 1.

Least squares means were calculated for each effect in model [1]. Herd least squares means were summarized with a frequency distribution. Overall herd mean, standard deviation among herd means, and the range of herd means also was calculated. Regional means, calculated as averages of herd least squares means, are also presented for US regions as defined in Figure 1.

Several alternative models were considered for investigation of factors affecting DD. Because dry off decisions are probably based primarily on what is occurring at the end of lactation, one alternative might be to use last test-day milk yield instead of lactational yield. Last test-day yield, however, is a poor choice of variable for determining the effect that level of production has on dry period. As an example, suppose 2 cows each have a calving interval of $400 \mathrm{~d}$ and both cows are dried off based on production. If cow 1 were dried off at 250 DIM, when milking $14 \mathrm{~kg} / \mathrm{d}$, it would have $150 \mathrm{DD}$. If cow 2 were dried off at 360 DIM, when milking $14 \mathrm{~kg} / \mathrm{d}$, it would have $40 \mathrm{DD}$. A large difference in dry period length exists between these 2 cows caused by production but, using last test-day yield, there is nothing to indicate their production difference. Conversely, these 2 cows would almost always have a difference in lactational yield. Thus, for determining how much of a role production plays in determining dry period length, last test-day yield is largely uninformative. This was borne out in a preliminary analysis that substituted last testday yield for lactational yield in model [1]. Last testday yield accounted for less than half the variation that lactational yield accounted for and differences in mean DD were less than $15 \%$ of those using lactational yield. Using a last test-day yield that is somehow adjusted for DIM may work better than simply the last test-day yield but use of lactational yield is adequate to address the general question of how much production affects dry period length.

Another alternative considered was lactational vs. last test-day SCS. Although SCS increases slightly at the end of lactation, it is much less sensitive to stage of lactation than milk yield (Miller et al., 2004). Preliminary analyses showed that last test-day SCS accounts for more variation than lactational SCS. Thus, last testday SCS, rather than lactational SCS, was used in the final model for analysis.

Days in milk was also considered for inclusion in model [1], but DIM was largely confounded with DO. Days open was chosen as the variable to include in the final analysis for several reasons. First, DIM was substituted for DO in a preliminary analysis and resulted in a lower coefficient of determination than did the model including DO. Days open is more of a causative agent toward dry period length than is DIM. Cows have long DIM in part because they had long DO. The days corresponding to the long open period are split between a longer lactation and a longer dry period. Thus, it is expected that DO would account for more variation in DD than DIM. Finally, DO, as a measure of fertility, is probably of more interest as a variable affecting dry period length. Least squares means for DIM from the preliminary analysis in which it was substituted for DO in model [1] are given in the results.

\section{Estimation of Heritability and Correlation}

The 2-trait animal model used for estimation of variances and covariances of DD with each of DO, 305-d, twice daily milking, mature-equivalent milk yield, SCS, fat percentage, and protein percentage was

$$
\begin{gathered}
\mathrm{y}=\mathrm{HY}+\text { YR_ST_MO }+\mathrm{b}_{1} \mathrm{Age}+\mathrm{b}_{2} \mathrm{Age}^{2} \\
+ \text { Parity }+\mathrm{a}+\mathrm{pe}+\mathrm{e},
\end{gathered}
$$

where HY is herd-year of calving, YR_ST_MO is yearstate-month of calving; Age is calving age fit as linear and quadratic covariates with regression coefficients $b_{1}$ and $b_{2}$; $a$ is the random animal effect, pe is a random $\mathrm{PE}$ effect, and e is random error. Herd-yr was used, instead of HY-season, to avoid small group sizes. Month was added to the model to account for season effects. Month effects were allowed to differ by state as well 


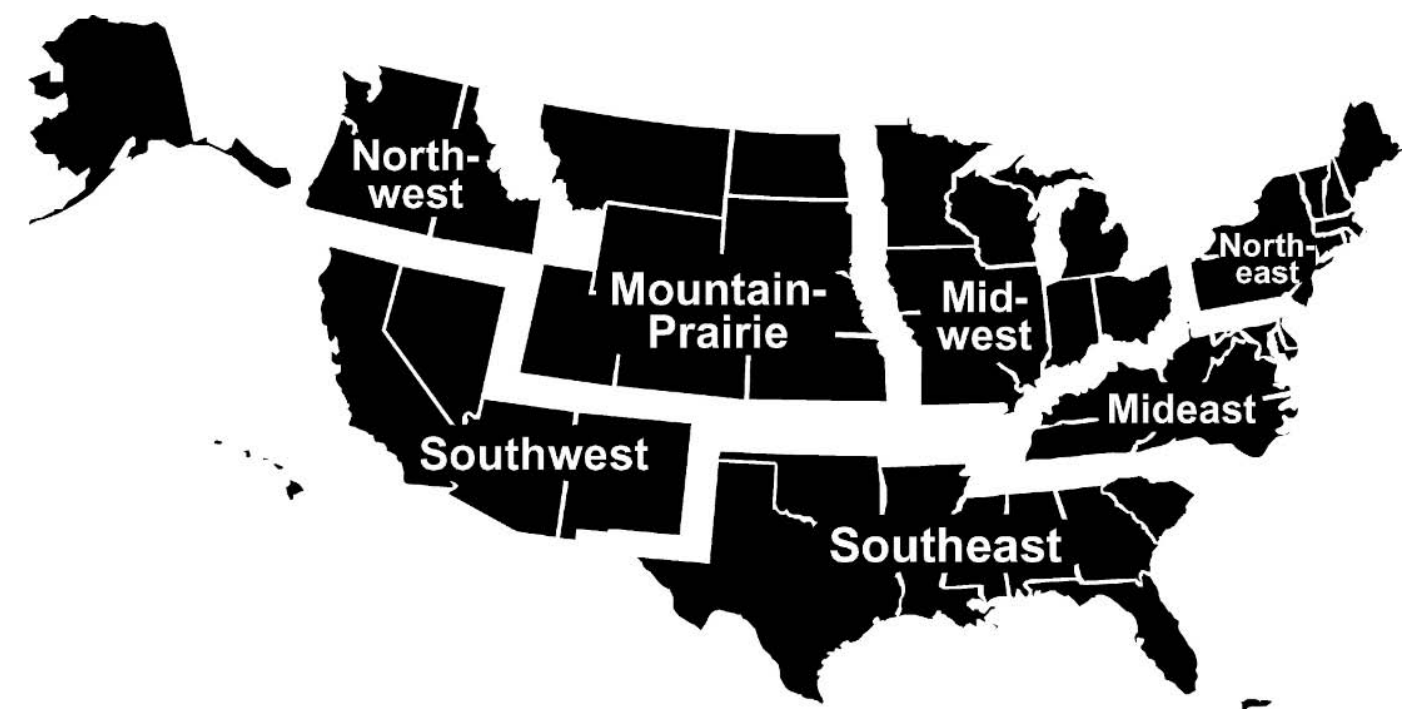

Figure 1. Definition of US regions. Mideast = Delaware, Kentucky, Maryland, North Carolina, Tennessee, Virginia, and West Virginia; Midwest = Illinois, Indiana, Iowa, Michigan, Minnesota, Missouri, Ohio, and Wisconsin; Mountain-Prairie = Colorado, Kansas, Montana, Nebraska, North Dakota, South Dakota, Utah, and Wyoming; Northeast = Connecticut, Maine, Massachusets, New Hampshire, New Jersey, New York, Pennsylvania, Rhode Island, and Vermont; Northwest = Alaska, Idaho, Oregon, and Washington; Southeast = Alabama, Arkansas, Florida, Georgia, Louisiana, Mississippi, Oklahoma, Puerto Rico, South Carolina, and Texas; and Southwest = Arizona, California, Hawaii, Nevada, and New Mexico.

year within state, hence YR-ST-MO. Co(variance) matrices for a, pe, and e were

$$
\begin{aligned}
\operatorname{Var}(\mathrm{a}) & =\left(\begin{array}{ll}
\mathrm{A} \sigma_{\mathrm{a} 1}^{2} & \mathrm{~A} \sigma_{\mathrm{a} 1, \mathrm{a} 2} \\
\mathrm{~A} \sigma_{\mathrm{a} 1, \mathrm{a} 2} & \mathrm{~A} \sigma_{\mathrm{a} 2}^{2}
\end{array}\right), \\
\operatorname{Var}(\mathrm{pe}) & =\left(\begin{array}{ll}
\mathrm{I} \sigma_{\mathrm{pe} 1}^{2} & \mathrm{I} \sigma_{\mathrm{pe} 1, \mathrm{pe} 2} \\
\mathrm{I} \sigma_{\mathrm{pe} 1, \mathrm{pe} 2} \mathrm{I} \sigma_{\mathrm{pe} 2}^{2}
\end{array}\right), \text { and } \\
\operatorname{Var}(\mathrm{e}) & =\left(\begin{array}{ll}
\mathrm{I} \sigma_{\mathrm{e} 1}^{2} & \mathrm{I} \sigma_{\mathrm{e} 1, \mathrm{e} 2} \\
\mathrm{I} \sigma_{\mathrm{e} 1, \mathrm{e} 2} & \mathrm{I} \sigma_{\mathrm{e} 2}^{2}
\end{array}\right),
\end{aligned}
$$

where $\mathbf{A}$ is a relationship matrix, $\mathbf{I}$ is an identity matrix, and $\sigma^{2}$ is a scalar variance.

Variances and covariances were estimated using REML. Only a random sample of the data, used to study factors affecting DD, was used for parameter estimation because the complete data set was more than could be handled computationally. Herds were randomly selected for inclusion. Each data set, used for parameter estimation, contained between 30,000 and 35,000 cows with records.

Days dry is related to previous lactation milk yield as well as milk yield in the subsequent lactation, but in different ways. Milk yield in the lactation before the dry period (e.g., lactation 1) partly determines the length of the dry period, but then the dry period length, in turn, has an effect on the subsequent lactation (e.g., lactation 2) yield. The correlations of DD with other traits could conceivably be different depending on whether the previous or subsequent lactation was used. When DD is associated with the previous lactation, milk yield would be a causative agent toward DD, whereas with subsequent lactation, the roles of cause and effect would be reversed. Therefore, correlations of DD with other traits were estimated for both previous and subsequent lactations. Because of the computing time involved, only 2 traits at a time were fit. Thus, correlations of DD with previous and subsequent lactations were estimated separately rather than simultaneously.

Correlation of DD with subsequent lactation traits implies that DD was missing for first lactation. To avoid selection bias, however, first lactations were still included, and DD was treated as missing for first lactation. For correlations of DD with previous lactation traits, DD was missing for the last lactation.

\section{RESULTS AND DISCUSSION}

\section{Descriptive Statistics}

Mean within-herd standard deviation of DD was 14 $\mathrm{d}$. The minimum within-herd variation was $2.2 \mathrm{~d}$, and the maximum was $33 \mathrm{~d}$. This range in standard deviations could reflect differences in management of dry period. Some herd managers may dry off all cows at a specific gestation length, whereas managers for herds with higher variation may regulate $\mathrm{DD}$ on an individual 
Table 2. Frequency distribution of individual dry period lengths.

\begin{tabular}{cccc}
\hline Days dry & Frequency & Percentage & $\begin{array}{l}\text { Cumulative } \\
\text { percentage }\end{array}$ \\
\hline $0-10$ & 2487 & 0.42 & 0.42 \\
$11-20$ & 1754 & 0.30 & 0.72 \\
$21-30$ & 5386 & 0.92 & 1.64 \\
$31-35$ & 6733 & 1.15 & 2.79 \\
$36-40$ & 14,059 & 2.40 & 5.20 \\
$41-45$ & 29,750 & 5.08 & 10.28 \\
$46-50$ & 59,602 & 10.18 & 20.46 \\
$51-55$ & 101,707 & 17.37 & 37.83 \\
$56-60$ & 122,585 & 20.94 & 58.76 \\
$61-65$ & 94,329 & 16.11 & 74.87 \\
$66-70$ & 48,824 & 8.34 & 83.21 \\
$71-80$ & 35,791 & 6.11 & 89.33 \\
$81-90$ & 18,065 & 3.09 & 92.41 \\
$91-100$ & 12,037 & 2.06 & 94.47 \\
$101-110$ & 8160 & 1.39 & 95.86 \\
$111-120$ & 5873 & 1.00 & 96.86 \\
$121-130$ & 4196 & 0.72 & 97.58 \\
$131-140$ & 3000 & 0.51 & 98.09 \\
$141-150$ & 2224 & 0.38 & 100.00 \\
$>150$ & 8940 & 1.53 & \\
\hline
\end{tabular}

cow basis determined by factors such as body condition or production level in addition to the number of days until calving. Mean within-herd standard deviations varied slightly across regions. Southwestern herds had the lowest standard deviation $(10 \mathrm{~d})$. All other regions had standard deviations of 14 to $15 \mathrm{~d}$.

Table 2 has the frequency distribution of individual DD records. Less than $3 \%$ of all dry periods included were less than $35 \mathrm{~d}$. About $65 \%$ of all dry periods were between 46 and $65 \mathrm{~d}$ and about $1.5 \%$ of dry periods were greater than $150 \mathrm{~d}$.

\section{Factors Affecting DD}

Table 3 presents mean squares for model [1] computed from SAS type III sums of squares (SAS Institute, 2004). Table 4 shows the least squares means for each effect except herd. Of the effects included in model [1], DO, by far, accounted for the most variation in DD. Longer DO result in longer dry periods. The difference

Table 3. Mean squares for factors affecting days dry.

\begin{tabular}{lrr}
\hline Effect $^{1}$ & df & \multicolumn{1}{c}{ MS } \\
\hline Herd & 3,526 & 3773 \\
Calving month & 11 & 13,637 \\
Calving year & 5 & 17,886 \\
Parity & 5 & 30,253 \\
Calving age & 5 & 6318 \\
Days open & 2 & $3,064,276$ \\
Lactation milk yield & 2 & $1,484,246$ \\
Last test-day SCS & 2 & 211,996 \\
Error & 455,516 & 166 \\
\hline
\end{tabular}

${ }^{1}$ All effects significant with $P<0.0001$.
Table 4. Least squares means and standard errors for factors affecting days dry.

\begin{tabular}{|c|c|c|c|}
\hline Category & Effect & LSM & $\mathrm{SE}$ \\
\hline \multirow[t]{12}{*}{ Calving month } & January & 61.6 & 0.36 \\
\hline & February & 61.5 & 0.36 \\
\hline & March & 61.2 & 0.36 \\
\hline & April & 60.3 & 0.36 \\
\hline & May & 59.2 & 0.36 \\
\hline & June & 59.2 & 0.36 \\
\hline & July & 59.5 & 0.36 \\
\hline & August & 59.5 & 0.36 \\
\hline & September & 60.0 & 0.36 \\
\hline & October & 60.8 & 0.36 \\
\hline & November & 61.4 & 0.36 \\
\hline & December & 61.6 & 0.36 \\
\hline \multirow[t]{6}{*}{ Calving year } & 1997 & 60.1 & 0.36 \\
\hline & 1998 & 61.0 & 0.35 \\
\hline & 1999 & 61.2 & 0.35 \\
\hline & 2000 & 61.1 & 0.35 \\
\hline & 2001 & 60.4 & 0.35 \\
\hline & 2002 & 59.2 & 0.45 \\
\hline \multirow[t]{6}{*}{ Parity } & 1 & 57.1 & 0.09 \\
\hline & 2 & 60.6 & 0.08 \\
\hline & 3 & 61.1 & 0.14 \\
\hline & 4 & 61.2 & 0.32 \\
\hline & 5 & 61.1 & 0.30 \\
\hline & 6 & 61.9 & 2.03 \\
\hline \multirow[t]{6}{*}{ Calving age } & $<24 \mathrm{mo}$ & 59.3 & 0.38 \\
\hline & 24 to $<30 \mathrm{mo}$ & 59.6 & 0.37 \\
\hline & 30 to $<36 \mathrm{mo}$ & 60.3 & 0.36 \\
\hline & 36 to $<42 \mathrm{mo}$ & 61.0 & 0.36 \\
\hline & 42 to $<48 \mathrm{mo}$ & 61.4 & 0.36 \\
\hline & $\geq 48 \mathrm{mo}$ & 61.6 & 0.35 \\
\hline \multirow[t]{3}{*}{ Days open } & Shortest & 55.6 & 0.35 \\
\hline & Medium & 59.0 & 0.35 \\
\hline & Longest & 66.9 & 0.35 \\
\hline \multirow[t]{3}{*}{ Lactational milk } & Lowest third & 65.0 & 0.35 \\
\hline & Middle third & 60.2 & 0.35 \\
\hline & Highest third & 56.3 & 0.35 \\
\hline \multirow[t]{3}{*}{ Last test-day SCS } & Lowest third & 59.5 & 0.35 \\
\hline & Middle third & 60.1 & 0.35 \\
\hline & Highest third & 61.9 & 0.35 \\
\hline
\end{tabular}

(3.4 d) in DD between cows with shortest and medium DO was small, but the difference in mean DD between cows with shortest and longest DO was $11.3 \mathrm{~d}$. When cows have delayed conception, their milk yield likely declines during the extended lactation to a point where keeping them in milk is no longer profitable and they are dried off, which results in long open as well as long dry periods. Excessively long dry periods associated with long DO is additional motivation to improve fertility through both genetics and management.

Least squares means for DD for the 3 DIM classes used in the preliminary analysis with DIM in place of DO were 58,58, and $62 \mathrm{~d}$ (with SE for each mean $\sim 0.34$ ). Longer lactations were associated with longer dry periods. The direction of difference was similar to that for DO, but the differences in DD associated with DIM were smaller than those for DO. 
Milk yield and SCS accounted for the second and third most variation in DD, respectively. As expected, high milk cows had the shortest DD (56 d), whereas the poorest producers had the longest DD (65 d). This simply indicates that cows are dried off according to production level. Cows with the highest SCS on last test-day had 2.4 more DD than those with the lowest SCS. This probably indicates that some cows that get mastitis near the end of lactation are dried off earlier than they would have been otherwise.

Cows had shorter ( 4 to $5 \mathrm{~d}$ ) dry periods after first lactation than after second and later lactations. Firstparity cows are more persistent than later parity cows (Stanton et al., 1992), which could influence managers to keep them milking longer. Differential culling may also account for part of the differences between parities. Only the more productive cows make it to second and later lactations and longer dry periods may be tolerated more for those cows than for first-lactation cows; a firstparity cow may instead get culled.

Although significant $(P<0.0001)$, month, year, and age at calving accounted for only a minimal amount of variation in DD. Cows calving in warmer months (May through August) had slightly shorter dry periods than cows calving in cooler months (especially November through February). The means in Table 4 indicate slightly shorter dry periods for 2002 , but this probably reflects a slight bias caused by the final date used for inclusion of records. Cows with long dry periods that calved late in 2002 may not have had the opportunity to calve again by the cutoff date. Age at calving had little influence on DD beyond the parity effect, although younger cows did have slightly fewer DD than did older cows.

In contrast to many traits of economic importance in dairy cattle, herd actually accounted for the smallest amount of variation in DD. The overall mean DD was $60.5 \mathrm{~d}$, and the standard deviation among herd means was $5.8 \mathrm{~d}$. The lowest herd mean was $28 \mathrm{~d}$, whereas the highest herd averaged $82 \mathrm{~d}$. The distribution of herd means is in Table 5 . About $65 \%$ of all herds maintained a mean DD between 56 and $65 \mathrm{~d}$. Although variation among herd means was low, 12 herds had a mean of $\leq 40 \mathrm{~d}$, and 2 herds had a mean DD of $\leq 30 \mathrm{~d}$. Thus, although most herd managers appear to be maintaining, on average, the traditional 60-d dry period, some are utilizing a shorter dry period. Some herds (125) had unusually long mean DD, exceeding $71 \mathrm{~d}$.

Variation across regions for DD (Table 6) was also minimal, although southwestern herds did show slightly longer mean DD than did herds in other regions. This may simply reflect differences in management, perhaps related to larger herd sizes that are more common in the western United States.
Table 5. Frequency distribution of herd least squares means for days dry.

\begin{tabular}{lccc}
\hline Days dry & Frequency & Percentage & $\begin{array}{l}\text { Comulative } \\
\text { percentage }\end{array}$ \\
\hline $0-10$ & 0 & 0.00 & 0.00 \\
$11-20$ & 0 & 0.00 & 0.00 \\
$21-30$ & 2 & 0.06 & 0.06 \\
$31-35$ & 1 & 0.03 & 0.09 \\
$36-40$ & 9 & 0.26 & 0.34 \\
$41-45$ & 29 & 0.82 & 1.16 \\
$46-50$ & 135 & 3.83 & 4.99 \\
$51-55$ & 367 & 10.41 & 15.40 \\
$56-60$ & 940 & 26.65 & 42.05 \\
$61-65$ & 1332 & 37.77 & 96.81 \\
$66-70$ & 587 & 16.64 & 99.91 \\
$71-80$ & 122 & 3.46 & 100.00 \\
$81-90$ & 3 & 0.09 & \\
\hline
\end{tabular}

\section{Heritabilities and Correlations}

Estimated standard deviations of random effects, for each trait, are given in the Appendix. Heritability of $\mathrm{DD}$, estimated from a single-trait animal model, was $7 \%$, and repeatability was $12 \%$. The $7 \%$ heritability was the same as that of Funk et al. (1987). It is in sharp contrast, however, to the heritabilities reported by Makuza and McDaniel (1996) for North Carolina herds, which were 0.41 for DD between first and second lactations and 0.49 for DD between second and third lactations. Ironically, their estimates for Zimbabwean cattle were in general agreement with the $7 \%$ found in this study. It is difficult to say what may have led to the unusually high estimates for the North Carolina herds, and Makuza and McDaniel (1996) did not speculate on this. Schaeffer and Henderson (1972) used Henderson's method 2 to estimate heritability of DD separately for parities 1 through 3; their estimates ranged from 0.15 to 0.34 . Although a commonly used method at that time, the methodology used by Schaeffer and Henderson (1972) was, as they noted, subject to bias, particularly by culling.

Correlations of DD with previous and subsequent mature-equivalent milk, fat and protein percentage, SCS, and DO are presented in Table 7 . The error correlations of -0.17 and 0.14 between DD and previous and subsequent lactation milk yield, respectively, indicate that high milk cows receive fewer DD, but cows afforded a longer dry period produce more milk in the subsequent lactation. The error correlations between DD and component percentages had signs opposite to those for milk yield, which is not surprising given the negative correlation between percentages and milk yield (Welper and Freeman, 1992). Cows with high fat and protein percentages tended to have longer dry periods, but cows with longer dry periods have lower percentages in the subsequent lactation. These results indicate that long 
Table 6. Summary of regional (Figure 1) least squares means for days dry.

\begin{tabular}{lccccc}
\hline & \multirow{2}{*}{$\begin{array}{l}\text { No. } \\
\text { Region }\end{array}$} & & \multicolumn{3}{c}{ Variation among herd means } \\
\cline { 4 - 6 } & 579 & Mean & SD & Minimum & Maximum \\
\hline Mideast & 140 & 60.9 & 5.73 & 34.1 & 80.9 \\
Mountain-Prairie & 342 & 59.5 & 6.07 & 39.7 & 70.3 \\
Midwest & 2143 & 60.5 & 6.31 & 27.9 & 80.5 \\
Northeast & 1 & 63.1 & 5.84 & 27.6 & 82.1 \\
Northwest & 299 & 61.4 & 5.14 & 41.3 & 77.1 \\
Southeast & 23 & 65.3 & 5.34 & 55.8 & 78.6 \\
Southwest & 3527 & 60.5 & 5.85 & 27.6 & 82.1 \\
Overall $^{1}$ & & &
\end{tabular}

${ }^{1}$ Overall Mean = arithmetic mean of individual herd least squares means. Overall SD = standard deviation among all individual herd least squares means.

dry periods are detrimental to fat and protein percentages and that protein is more affected than fat. Cows with high SCS have longer DD than cows with lower SCS as indicated by the error correlation of 0.07 with previous lactation. However, long dry periods favor somewhat improved SCS in the subsequent lactation, as indicated by the error correlation of -0.05 with subsequent lactation.

One of the most noticeable features of the genetic and PE correlations is that they tended to differ depending on whether DD was correlated with previous or subsequent lactation. The genetic correlation between DD and milk yield, for example, was -0.38 for previous lactation and -0.62 for subsequent lactation. Although consistent in direction, they are different in magnitude. The PE correlations between DD and milk yield were 0.19 for previous lactation and -0.89 for subsequent lactation, which differed in both magnitude and direction. It might be expected that these correlations would be similar.

What this reflects, however, is a partitioning of the DD effect, across model terms, an effect which is present in the subsequent lactation record but not in the previous. Consider the following simplified model for firstlactation yield $\left(\mathrm{y}_{1}\right)$ :

$$
\mathrm{y}_{1}=\mathrm{A}_{\mathrm{m}}+\mathrm{PE}_{\mathrm{m}}+\mathrm{e}_{\mathrm{m} 1}
$$

where $A_{m}$ is breeding value for milk yield, $\mathrm{PE}_{\mathrm{m}}$ is a permanent environmental effect for yield, and $\mathrm{e}_{\mathrm{m} 1}$ is a first-lactation error. Given the correlation of DD with previous yield, an equation for DD between first and second lactations $\left(\mathrm{DD}_{1}\right)$ can be written as:

$$
\mathrm{DD}_{1}=\beta_{\mathrm{a}} \mathrm{A}_{\mathrm{m}}+\beta_{\mathrm{pe}} \mathrm{PE}_{\mathrm{m}}+\beta_{\mathrm{e}} \mathrm{e}_{\mathrm{m} 1}+\mathrm{e}_{\mathrm{d}}
$$

where $\beta_{\mathrm{a}}, \beta_{\mathrm{pe}}$, and $\beta_{\mathrm{e}}$ are regressions of DD breeding value, $\mathrm{PE}$, and error on milk yield breeding value, $\mathrm{PE}$, and error, respectively, and $\mathrm{e}_{\mathrm{d}}$ is an independent error term. An equation for second-lactation yield would be:

$$
\mathrm{y}_{2}=\mathrm{A}_{\mathrm{m}}+\mathrm{PE}_{\mathrm{m}}+\mathrm{DD}_{-} \text {effect }_{1}+\mathrm{e}_{\mathrm{m} 2}
$$

where DD_effect ${ }_{1}$ is the effect of DD associated with a dry period of length $\mathrm{DD}_{1}$. The covariances of $\mathrm{y}_{1}$ and $\mathrm{y}_{2}$ with $\mathrm{DD}_{1}$ are:

$$
\begin{aligned}
\operatorname{Cov}\left(\mathrm{y}_{1}, \mathrm{DD}_{1}\right)= & \beta_{\mathrm{a}} \sigma_{\mathrm{Am}}{ }^{2}+\beta_{\mathrm{pe}} \sigma_{\mathrm{PEm}}{ }^{2}+\beta_{\mathrm{e}} \sigma_{\mathrm{em}}{ }^{2} \\
\operatorname{Cov}\left(\mathrm{y}_{2}, \mathrm{DD}_{1}\right)= & \operatorname{Cov}\left(\mathrm{y}_{1}, \mathrm{DD}_{1}\right)+\operatorname{Cov}\left(\mathrm{DD}_{-}\right. \text {effect } \\
1 & \left.\mathrm{DD}_{1}\right) \\
= & \operatorname{Cov}\left(\mathrm{y}_{1}, \mathrm{DD}_{1}\right)+\operatorname{Cov}\left(\mathrm{DD}_{-}\right. \text {effect } \\
1 & \beta_{\mathrm{a}} \mathrm{A}_{\mathrm{m}} \\
& \left.+\beta_{\mathrm{pe}} \mathrm{PE}_{\mathrm{m}}+\beta_{\mathrm{e}} \mathrm{e}_{\mathrm{m}}+\mathrm{e}_{\mathrm{d}}\right) .
\end{aligned}
$$

Considering DD_effect ${ }_{1}$ as a random variable, the probability of occurrence of DD_effect ${ }_{1 i}$ is the same as

\begin{tabular}{|c|c|c|c|c|c|c|c|c|}
\hline \multirow[b]{2}{*}{ Trait } & \multicolumn{4}{|c|}{ Previous lactation } & \multicolumn{4}{|c|}{ Subsequent lactation } \\
\hline & a & pe & $\mathrm{e}$ & $\mathrm{P}$ & $\mathrm{a}$ & pe & e & $\mathrm{P}$ \\
\hline Milk yield & -0.38 & 0.19 & -0.17 & -0.15 & -0.62 & -0.89 & 0.14 & -0.06 \\
\hline Fat percentage & 0.13 & -0.04 & 0.05 & 0.04 & 0.16 & 0.15 & -0.06 & -0.01 \\
\hline Protein percentage & 0.20 & -0.58 & 0.14 & 0.07 & 0.21 & 0.64 & -0.20 & -0.02 \\
\hline SCS & -0.17 & 0.06 & 0.07 & 0.05 & -0.23 & 0.42 & -0.05 & 0.01 \\
\hline Days open & 0.12 & 1.00 & -0.06 & 0.02 & 0.14 & 1.00 & -0.06 & 0.02 \\
\hline
\end{tabular}
the probability of occurrence of $\mathrm{DD}_{1 \mathrm{i}}$. Thus, DD_effect and $\mathrm{DD}_{1}$ are clearly correlated and if $\mathrm{DD}_{1}$ is correlated with $\mathrm{A}_{\mathrm{m}}, \mathrm{PE}_{\mathrm{m}}$, and $\mathrm{e}_{\mathrm{m}}$, the DD effect will be as well. Hence, the DD effect will contribute to genetic and envi-

Table 7. Genetic (a), permanent environment (pe), error (e), and phenotypic (P) correlations of days dry with mature-equivalent milk yield, fat percentage, protein percentage, SCS, and days open. 
ronmental correlations when DD is associated with subsequent lactation.

With the exception of milk yield, genetic correlations between DD and other traits (Table 7) were generally the same for previous and subsequent lactations. The negative genetic correlations between mature-equivalent milk yield and DD were consistent with the findings of Schaeffer and Henderson (1972), who reported genetic correlations ranging from -0.18 to -0.41 across parities. One implication of the nonzero genetic correlations between DD and milk yield is that caution and further research are warranted before implementing a correction for DD in genetic evaluation for milk yield, in spite of relatively low heritability for DD. Such research, perhaps using simulation, should determine the amount of the breeding value that would be partitioned out of the animal effect and the possible long-term consequences of such a partitioning. Furthermore, with an error correlation between DD and milk yield in subsequent lactation of only 0.14 , the benefit of adjusting for DD (correction for a known environmental effect) may be less than the cost (redefinition of the trait or bias relative to total breeding value for the original trait).

As with the error correlations, the genetic correlations between DD and component percentages were opposite in sign compared with those for milk yield and generally of lower magnitude as well. The negative genetic correlation between DD and SCS indicates that cows that are genetically prone to high SCS have lower breeding values for DD. This finding may seem somewhat peculiar because high SCS would be expected to be associated with longer DD (a positive correlation), rather than shorter DD, as indicated in Table 4. The genetic relationship between DD and SCS may result from their relationships with milk yield. Breeding value for high milk yield is associated with breeding value for poorer SCS (Welper and Freeman, 1992). High breeding value for milk yield, then, may lead to breeding values for higher SCS but also for shorter dry period.

The PE correlation of 0.19 between DD and previous lactation milk yield indicates that PE effects for high production tend to predispose the cow toward longer dry periods. However, the -0.89 correlation for subsequent lactation milk yield shows that cows with PE effects for high production tend to receive low DD effects. The genetic and PE correlations for subsequent lactation milk yield clearly indicate that cows with inherent highproducing ability receive the shortest dry periods.

The genetic and PE correlations of DD with DO converged to 1 . Table 3 shows that DO had the most pronounced effect on DD. Table 7 indicates that the magnitude of that effect resulted mainly from additive genetic and PE components and those components are not subject to quick and easy change. Milk yield or SCS in the subsequent lactation, for example, could be improved simply by deciding to give the cow a longer dry period as indicated by the subsequent lactation error correlations for those traits. However, manipulation of DD is not an answer for cows with long DO because such cows are almost certainly dried off and receive longer dry periods because the producer believes that keeping them in milk is no longer economically prudent. Genetic improvement of female fertility, along with identification of and improvement in environmental factors that have permanent effects on female fertility, will be a useful, if not necessary, companion for viable shortened dry periods.

The error correlations of DD with DO were low. The -0.06 error correlation with subsequent DO does imply some reproductive benefit of a shortened dry period, but that benefit may result from the reduced milk yield associated with fewer DD as implied by the 0.14 error correlation with milk yield.

The error correlations in this study indicate direction of difference but not magnitude of difference. The positive error correlation (0.14) between DD and subsequent lactation yield, for example, implies that production increases as DD increases. However, the magnitude of differences, or what particular DD maximizes performance in the subsequent lactation, cannot be gleaned from these results. Further research should reexamine the effect of DD on subsequent lactation using recent data not only for production but for components, SCS, and fertility as well. One implication of the large genetic and $\mathrm{PE}$ correlations between $\mathrm{DD}$ and the other traits in subsequent lactation is that correction for cow effects is warranted in studies aimed at discerning the effect of DD on subsequent lactation performance.

\section{CONCLUSIONS}

Herds included in this study averaged 60.5 DD and variation among herd means was minimal (standard deviation of $5.8 \mathrm{~d}$ ). Of the factors considered in this study, DO had the greatest impact on DD. Cows with longer DO had longer dry periods. Milk yield was the second most important factor in determining DD, with high yielding cows having fewer DD. Cows with lower SCS and first-lactation cows had slightly shorter dry periods.

Heritability and repeatability estimates for DD were $7 \%$ and $12 \%$, respectively, and were generally consistent with previously published research. Sizeable genetic correlations warrant caution and further study before following recommendations to correct for DD in genetic evaluation. The relationship between DD and DO results largely from permanent cow effects that are 
not quickly or easily manipulated. Genetic and environmental improvement in factors affecting reproduction will enhance the viability of shortened dry periods.

Further research should reexamine the effect of DD on subsequent lactation using recent data. Most genetic and $\mathrm{PE}$ correlations were of a sizeable magnitude, which indicates that correction for cow effects in such studies would be warranted.

\section{ACKNOWLEDGMENTS}

The authors thank Shogo Tsuruta and Ignacy Misztal for the use of their AIREMLF90 program and Keith Boldman and Dale VanVleck for the use of their MTDFREML program. Appreciation is extended to Paul VanRaden for helpful discussions. The cooperation of the dairy records processing centers in supplying yield and pedigree data for use in genetic and management research is acknowledged.

\section{REFERENCES}

Animal Improvement Programs Laboratory. 2004. Data collection rating. November, 2004. Online. Available: http://aipl.arsusda.gov/reference/datarating.htm. Accessed Nov. 8, 2004.

Animal Improvement Programs Laboratory. 2004a. Owner-sampler records. November, 2004. Online. Available: http://aipl.arsusda.gov/reference/useos.htm. Accessed Nov. 8, 2004.

Annen, E. L., R. J. Collier, and M. A. McGuire. 2003. Older cows fared well without a dry period. Hoard's Dairyman 148:650.

Bachman, K. C. 2002. Milk production of dairy cows treated with estrogen at the onset of a short dry period. J. Dairy Sci. 85:797-803.

Bachman, K. C. 2004. Will shorter dry periods pay for you? Hoard's Dairyman 149:321.

Bachman, K. C., and M. L. Schairer. 2003. Bovine studies on optimal lengths of dry periods. J. Dairy Sci. 86:3027-3037.

Coppock, C. E., R. W. Everett, R. P. Natzke, and H. R. Ainslie. 1974. Effect of dry period length on Holstein milk production and selected disorders at parturition. J. Dairy Sci. 57:712-718.

Dias, F. M., and F. R. Allaire. 1982. Dry period to maximize milk production over two consecutive lactations. J. Dairy Sci. 65:136-145.

Funk, D. A., A. E. Freeman, and P. J. Berger. 1987. Effects of previous days open, previous days dry, and present days open on lactation yield. J. Dairy Sci. 70:2366-2373.

Grummer, R. 2004. Here's more on short dry periods. Hoard's Dairyman 149:142.

Makuza, S. M., and B. T. McDaniel. 1996. Effects of days dry, previous days open, and current days open on milk yields of cows in Zimbabwe and North Carolina. J. Dairy Sci. 79:702-709.
Miller, R. H., H. D. Norman, G. R. Wiggans, and J. R. Wright. 2004. Relationship of test-day somatic cell score with test-day and lactational milk yields. J. Dairy Sci. 87:2299-2306.

Rastani, R., and R. Grummer. 2003. Shorter dry periods look good. Hoard's Dairyman 148:599.

SAS Institute. 2004. OnlineDoc. Version 9.1.2. SAS Inst., Inc., Cary, NC.

Sargent, F. D., V. H. Lytton, and O. G. Wall, Jr. 1968. Test interval method of calculating dairy herd improvement association records. J. Dairy Sci. 51:170-179.

Schaeffer, L. R., and C. R. Henderson. 1972. Effects of days dry and days open on Holstein milk production. J. Dairy Sci. 55:107-112.

Shook, G. E., L. P. Johnson, and F. N. Dickinson. 1980. Factors for improving accuracy of estimates of test-interval yield. DHI Lett. $56: 9-24$.

Stanton, T. L., L. R. Jones, R. W. Everett, and S. D. Kachman. 1992. Estimating milk, fat, and protein lactation curves with a test day model. J. Dairy Sci. 75:1691-1700.

Welper, R. D., and A. E. Freeman. 1992. Genetic parameters for yield traits of Holsteins, including lactose and somatic cell score. J. Dairy Sci. 75:1342-1348.

\section{APPENDIX}

Estimates of variance components are often difficult to find in the literature even for commonly analyzed traits such as production. For DD, estimates of genetic, $\mathrm{PE}$, and error variances are virtually nonexistent in published literature. These variance components are often needed in research or when considering appropriate parameters for genetic evaluation. Although not of primary interest in this study, estimates of genetic, $\mathrm{PE}$, error, and phenotypic standard deviations from this research are provided in Table A1 for DD, DO, and mature-equivalent milk yield, fat percentage, protein percentage, and SCS.

Table A1. Estimates of genetic (a), permanent environment (pe), error (e), and phenotypic (P) standard deviations for days dry; matureequivalent milk yield, fat percentage, protein percentage, and SCS; and days open.

\begin{tabular}{lrrrr}
\hline Trait & \multicolumn{1}{c}{ a } & \multicolumn{1}{c}{ pe } & \multicolumn{1}{c}{$\mathrm{P}$} \\
\hline Days dry & 3.55 & 2.68 & 12.96 & 13.70 \\
Milk yield, kg & 755.97 & 748.92 & 1115.01 & 1541.30 \\
Fat percentage & 0.28 & 0.19 & 0.22 & 0.41 \\
Protein percentage & 0.14 & 0.06 & 0.09 & 0.18 \\
SCS & 0.44 & 0.57 & 0.97 & 1.21 \\
Days open & 15.13 & 18.51 & 70.98 & 74.90 \\
\hline
\end{tabular}

